\title{
Australian Contributions to Coconut (Cocos nucifera L.) Research (A Review Article)
}

\author{
Mike Foale and Steve Adkins ${ }^{1}$
}

\begin{abstract}
Australia has been a significant supporter of research into coconut protection, improvement and biotechnology for three decades. Major achievements include a key role in identification of the Cadang Cadang Viroid in Philippines and the Foliar Decay virus in Vanuatu, surveys of coconut genetic diversity in the south Pacific, and the initiation of global collaboration leading to the formation of the Coconut Genetic Resources Network.

Another major Australian contribution beginning in the 1980s, has been to the development and refinement of methods of collection and exchange around the world of diverse coconut genotypes under COGENT involving particularly the protocol for embryo transfer and culture. Most recently $\mathrm{CO} 2$ enrichment of the in vitro atmosphere has raised cultured embryo growth to a new level at the University of Queensland (UQ). Researchers at UQ have brought somatic embryogenesis, a critical process for multiplication of high-value individual palms, to the verge of commercial application, has and also greatly advanced the technique for preserving genetic material by cryopreservation of the embryo. The development of a healthy and high-value snack food from coconut kernel has also emerged at UQ.

Modest additional funding would advance all of these recent projects to the stage of general application, thereby building on the strong record of Australia in helping to secure the future of coconut producers in the community and economy of Pacific nations, and beyond.
\end{abstract}

\footnotetext{
${ }^{1}$ School of Agriculture and Food Sciences, University of Queensland, Australia.

Email: mikefoale@bigpond.com
} 


\section{Introduction}

Coconut (Cocos nucifera L.) oil, which had been the first "vegetable oil" to be traded world-wide, beginning in the $19^{\text {th }}$ Century, reached a peak in its level of production and value in the first decades of the 20th century. In Europe, the Americas and Australia its use and popularity grew until the mid-20 ${ }^{\text {th }}$ Century, by which time the steady growth of supplies of competing oils from soy (Glycine $\max (\underline{\mathrm{L}}$. Merr.), cotton-seed (Gossypium spp.), sunflower (Helianthus annuus L.), canola (Brassica napus L.), oil palm (Elaeis guineensis Jacq.) and others began to have an impact (Foale 2003). The fall in relative value of coconut oil was then accelerated as a result of a campaign initiated by the soy industry in the USA to discredit its health value. Investment in large coconut plantations, having reached by the 1960 s an age that required replanting, declined to the point that smallholders became the mainstay for coconut production by the 1980s. In responding to these historical events the Australian government sought to assist its neighbouring countries in sustaining their coconut and other agricultural industries' output, as a key component of their respective economies, by initiating the Australian Centre for International Agricultural Research (ACIAR).

ACIAR began supporting coconut research projects in the Philippines and the south Pacific in the early 1980s (Ashburner et al 1991; Samosir et al. 2006b). During that time major contributions were made by Australian scientists identifying the viroid which causes Cadang Cadang in the Philipines, and the virus which causes Foliar Decay in Vanuatu (Hanold et al. 1988). There was also a significant initiative in ACIAR's Coconut Improvement Project, focussing particularly on Papua New Guinea, and which expanded into a wider context, contributing to the formation of the Coconut Genetic Resources Network (COGENT) in the 1990s, which had a global mandate.

In collaboration with COGENT there were major contributions from ACIAR to research on the technology for coconut embryo culture (Magdalita et al 2010a and 2010b; Samosir
1999; Samosir and Adkins 2005 and 2014b; Samosir et al. 1999a, 1999b and 2006c). For germplasm transfer, the embryo rather than the whole nut is preferred in order to reduce the cost and phytosanitary risk when exchanging germplasm to gain knowledge of genetic diversity and undertake selection and breeding. There was also support from ACIAR for somatic embryogenesis (Samosir 1999; Nikmatullah 2001; Antonova 2009). That elusive goal was first attained by English researchers (Branton and Blake 1983), but proved exceedingly hard to repeat reliably and affordably by others (Verdeil et al. 1994).

Embryo culture has continually been researched in the Philippines in order to disseminate the makapuno gene(s) which generate fruit valued up to ten times more than a normal mature coconut fruit. The University of Queensland (UQ) formed a coconut group in the late 1990s and with ACIAR support was able to contribute significant advances to embryo culture in terms of the rate of growth of the plantlet and the proportion of plantlets successfully transferred ex vitro to seedlings in soil (Adkins and Samosir 2002; Magdalita et al. 2006a and 2006b; Samosir et al 2006; Samosir and Adkins 2014; UQ has also successfully refined the technique of cryopreservation of mature coconut embryos from which a $40 \%$ recovery rate to normal seedling growth was achieved (Adkins and Foale 2014). This offers the alternative possibility of preserving genetic material securely without the costs and risks associated with a field gene bank (Sisunandar 2008; Sisunandar et al. 2010a and 2010b; Sisunandar et al. 2013).

Work has also been undertaken to develop a snack food from coconut kernel that is free of added sugar (Foale 2014). It has become clear in recent years that the hypothesis adopted in the markets for edible oils that coconut was a health risk is entirely without foundation. Any new food products that deliver coconut oil in a highly palatable, sugar-free medium into the food market will be of great nutritional value.

The purpose of this paper is to summarise Australian contributions to coconut research, and in some cases present published evidence of 
these achievements. It is also intended to discuss how these technologies might support major advances in the value of coconut fruit and their products? produced by small-holder farmers in the south Pacific if funding can be found for final refinement and confirmation of developed protocols, leading to technology transfer.

\section{Research}

The topics to be addressed in this paper are: embryo culture development and transfer to new genebanks; somatic embryogenesis; cryopreservation of embryos; and product development to render the coconut kernel more popular as human food.

Embryo culture: This has been researched for decades in the Philippines, stimulated by the enhanced value of the "soft kernel" mature nut, known as makapuno, produced as a result of mutation(s). The embryo is present in such a nut, but as the endosperm cannot support its germination and the only way to germinate this type of coconut palm was to artificially culture the otherwise doomed embryo, thereby expanding the productive population of mutant palms.

The outstanding work over several decades done by Philippine researchers and the Coconut Improvement Project of ACIAR (Ashburner et al 1991) was summarised by Orense et al. (2011). This has led to a great expansion of the local population of makapuno-producing palms and early embryo exchanges within COGENT. The process has been successively rendered more efficient and recently an ACIAR-supported project at UQ has contributed further to the rate of growth (Madalita et al. 2006a, b) and robustness of the seedlings generated by embryo culture. (Samosir et al. 2006; Samosir and Adkins 2014; in press) report that the $\mathrm{CO}_{2}$ enrichment of the head space of germinated embryos provides a significantly improved outcome for a range of genotypes.

It is anticipated that the protocol developed through the ACIAR project, with additional training, will enable embryo culture to be more successfully transferred to new research groups previously inexperienced in such work.
There has been a poor past record in the south Pacific for the transfer of embryo culture technology due in part at least to a low level of vigour during the early stages of growth, and at the point of transfer from laboratory to a soil medium.

The makapuno trait, along with a number of different genotypes generating aromatic fruit water, have the potential to boost farmers' incomes throughout the coconut world (Samosir et al. 2006). Whereas the small-holder receives a modest return for effort delivering copra or whole nuts for sale at the farm gate, the greatly increased value of makapuno (Orense et al. 2011), and aromatic water fruit, may generate up to a ten-fold increase in income. Such an outcome requires an initial investment in the process of transferring the advanced embryo culture technique to national agriculture authorities and perhaps private investors, in order to generate a population of palms carrying the elite characters of makapuno or aromatic fruit water.

Somatic embryogenesis: Despite the longawaited announcement that coconut had been successfully cloned from non-zygotic tissues (Branton and Blake 1983) and a subsequent single cloned Rennell Tall by Malayan Orange Dwarf hybrid plant transferred to the field in Solomon Islands (Unilever, pers comm 1985) a reliable protocol was not achieved. Repetition of the successful in vitro procedure to render proliferating callus tissue consistently embryogenic has failed.

Researchers in Mexico have achieved repeatable embryogenesis from callus generated from embryo tissues. However, because of its zygotic nature (Islas-Flores et al. 1998), the process embodies a degree of genetic uncertainty as to the potential of the cloned progeny. Research at UQ showed a very significant improvement in the rate of somatic embryogenesis from zygotic (Samosir 1999a and 1999b) and somatic tissues (Antonova, 2009; Nikmatullah, 2001). Over a period of 8 months callus was grown from inflorescence tissue which by extrapolation would have generated 2000 embryos of which 1100 germinated and 
620 progressed to become plantlets (Antonova, 2009). The possibility of building upon this work to develop an affordable protocol from somatic embryogenesis is high, requiring a modest further investment to realise a reliable protocol.

Success with somatic embryogenesis from somatic tissues would enable the cloning of any palm showing an elite trait. Of particular interest in view of their current market value are makapuno and aromatic fruit types. There have been reports in PNG, French Polynesia and Solomon Islands of isolated makapuno palms that could be the progenitors for a cloned population enabling short-term multiplication of palms. It is highly likely that similar mutant types exist in other south Pacific countries. It would be wise to identify such palms in the local population, expected to be better adapted than exotic genotypes to the specific biological enemies of the coconut that are present.

Cryopreservation: The principal aim of COGENT (Coconut Genetic Resources Network) founded in 1993 has been to establish and maintain coconut genebanks in representative locations around the world. There has been mixed success with five collections, hosting hundreds of genotypes, now established in Brazil, Ivory Coast, India, Indonesia and Papua New Guinea. Apart from the cost of establishing these collections, their upkeep in some cases has also been very expensive and barely affordable, and there is an attendant risk of loss due to destructive weather events or the assault of insect or pathogen species on some genotypes. As an alternative to the costly field gene-bank the cryopreservation technique (Engelmann 2011) has been applied to coconut embryos.

UQ has reported excellent progress, and more recently the recovery after cryopreservation has been very favourable indeed (Sisunandar 2008; Sisunandar et al. 2010a, 2010b and 2013); Modest further investment in this work would readily yield a robust protocol ready for immediate use as a backup for genotypes in existing gene-banks for which the original source population is still secure. The prospect of preserving genotypes by generating embryos through controlled pollination is not attractive, owing to the very high cost of that pollination process.

Coconut food products: The best known edible form of coconut outside of the tropics is desiccated kernel of various fine particle sizes, shredded strips and flakes. The composition of these remains the same as the kernel itself comprising in the anhydrous state generally $70 \%$ oil, $7 \%$ protein, $5 \%$ sucrose and $18 \%$ "crude fibre" (Child, 1974). According to Raghavendra et al. (2004) after testing 15 sources, "coconut kernel fibre showed a higher swelling capacity than any other [edible] fibre studied" indicating that it helps regulate transit time in the digestive system in a very favourable way.

Desiccated coconut is generally used in baking and topping of cakes and desserts, almost invariably in combination with copious amounts of sugar. As one of the major concerns in the modern diet is the unfavourable effect of high sugar intake, a quest for coconut products that are attractive and palatable without added sugar has been initiated.

Preliminary tests at UQ (Foale, unpublished) have shown that a very palatable snack "nutlet" can be produced on any scale from the home kitchen upwards, derived from a kernel strip $5 \mathrm{~mm}$ thick, sun dried or kiln dried, and then deep fried at $120 \mathrm{C}$ in coconut oil until a light brown coour develops (Foale 2014). Funding is needed to develop mechanisation of the initial preparation of the fresh nutlets, and to characterise the product with chemical analysis. This product could become a household item in the coconut world due to the simplicity of the process. The nutlet contains all the components listed above and its richness in oil delivers the plethora of health benefits (Foale 2003) that have been experienced by those consuming coconut oil in their regular diet.

\section{Conclusion}

The record presented here shows that coconut research has received significant support from Australian institutions over three decades. The final refinement of the methods of 
cryopreservation and somatic embryogenesis at the University of Queensland depends on further modest funding support to be realised.

\section{References}

Adkins, S.W., Samosir, Y.M. and Godwin, I.D. 1999. Control of environmental conditions and the use of polyamines can optimise the conditions for the initiation and proliferation of coconut somatic embryos. In: Coconut Biotechnology (Ed. C. Oropeza). CAB International, UK. pp 321340.

Adkins, S.W. and Y.M.S. Samosir 2002. Embryo culture activities at the University of Queensland, Australia. In: Coconut Embryo in vitro Culture: Part II. (Eds. F. Engelmann, P. Batugal and L. Oliver). Merida, Mexico. pp 163-168.

Adkins, S.W., Samosir, Y.S., Nikmatullah, A. and Ogle, H. 2005. Coconut (Cocos nucifera L.) In Vitro Ecology: Modification of headspace and medium additives can optimise somatic embryogenesis. Acta Horticulturae, 692: 21-31.

Adkins, S.W., Foale, M. and Samosir, Y.M.S. 2006. Coconut Revival: New Possibilities for the 'Tree of Life', ACIAR Proceedings Number 125. PUBLISHER

Adkins, S.W. and Foale, M. 2014. The role of tissue culture in germplasm collection, conservation, multiplication the potential application to high valued coconut types. ACIAR SPC Pacific coconut workshop Tanoa Tusitala Hotel, Apia, Samoa, 31st October - $2^{\text {nd }}$ November 2012. In Press.

Antonova, I. 2009. Somatic embryogenesis for micropropagation of coconut (Cocos nucifera L.) PhD Thesis. The University of Queensland.

Ashburner GR, Thompson WK, Maheswaran G and Burch JM 1991. The effect of solid and liquid phase in the basal medium of coconut (Cocos nucifera L.) embryo cultures. Oleagineux 46, 149-152.
Branton J. and Blake J. 1983. A lovely clone of coconuts. New Scientist VOL??554-557

Child, R. 1974. Coconuts. $2^{\text {nd }}$ edition. Longman, London.

Engelmann, F. 2011. Cryopreservation of embryos: an overview. Methods in Molecular Bioliology 710: 155-184.

Foale MA (2003). The Coconut Odyssey. ACIAR Monograph 101, Canberra.

Foale, M.A. 2014. New products and processing technology In: Proceedings of. ACIAR SPC Pacific coconut workshop Tanoa Tusitala Hotel, Apia, Samoa, 31st October- $2^{\text {nd }}$ November. 2012. In Press.

Hanold, D., Langridge, P. and Randles J.W. 1988. The use of cloned sequences for the identification of coconut foliar decay disease associated DNA. Journal of Gen Virology 69: 1323-1329.

Islas-Flores, I.I., Oropeza, C., HernandezSotomayor, S.M. 1998. Protein phosphorylation during coconut zygotic embryo development Plant Physiology. 118(1): 257-263.

Magdalita, P.M., Damasco, O.P. and Adkins, S.W. 2010a. Effect of medium replenishment and acclimatization techniques on growth and survival of embryo cultured coconut seedlings. Philippine Science Letters 3(2): 1-9.

Magdalita, P.M., Damasco, O.P. and Adkins, S.W. 2010b. Effect of chemical and physical treatments on the in vitro germination and growth of 'Laguna Tall' coconut embryos. Philippine Journal of Crop Science 35(3): 41-49.

Nikmatullah, A. 2001. Towards the clonal propagation of coconut (Cocos nucifera L.). MPhil Thesis. The University of Queensland.

Orense, O.D., Rillo, E.P., Alexie, L., Imperia,1 P., Cueto, C.S., Lobos, A.A. and Areza, M.B.B. 2011. Rapid and cost-effective embryo culture technique for commercial 
production of makapuno seedlings. Cord 27(1): 20-41.

Raghavendra, SN., Rastogi, N.K., Raghavarao, K.S.M.S., and Tharanathan, R.N. (2004) Dietary fibre from coconut residue: effects of different treatments and particle sizes on the hydration properties. European Food Res and Technology, 218: 563-567.

Samosir, Y. 1999. Optimisation of Somatic Embryogenesis in Coconut (Cocos nucifera $\mathrm{L}$.). $\mathrm{PhD}$ Thesis. The University of Queensland.

Samosir, Y.M., Godwin, I.D. and Adkins, S.W. 1999a. The use of osmotically active agents and abscisic acid can optimise the maturation of coconut somatic embryos. In: Coconut Biotechnology. (Ed. C. Oropeza). CAB International, UK. pp 341354.

Samosir, Y.M.S., Godwin, I.D. and Adkins, S.W. 1999b. A new technique for coconut (Cocos nucifera L.) germplasm collection from remote sites: culturability of embryos following low temperature incubation. Australian Journal of Botany, 47: 69-75.

Samosir, Y.M.S. and Adkins, S.W. 2005. Embryo transplantation for germplasm exchange and establishment of high value mutant coconut types. In: Proceedings of the Plant Tissue Culture and Biotechnology Conference; Contributing to a sustainable future. Perth, Australia, 21-24 September, 2005. pp 187-194. Eds. Bennett, I., Bunn, E., Clarke, H., and McComb, J. The Australian Plant Breeding Association. Inc.

Samosir, Y.M.S., Foale, M. and Adkins, S.W. 2006a. Coconut World: an opportunity for northern Queensland. In: Coconut revival: new possibilities for the 'tree of life', Proceedings of the International Coconut Forum, Cairns, Australia, 22-24 November, 2005. Eds. S.W. Adkins, M. Foale and Samosir, Y.M.S., pp 80-86. ACIAR Proceedings Number 125. Publisher
Samosir, Y.M.S., Foale, M. and Adkins, S.W. 2006b. Australian involvement in coconut research and development. In: Coconut revival: new possibilities for the 'tree of life', Proceedings of the International Coconut Forum, Cairns, Australia, 22-24 November, 2005. Eds. S.W. Adkins, M. Foale and Samosir, Y.M.S., pp 36-42. ACIAR Proceedings Number 125. Publisher.

Samosir, Y.M.S., Rillo, E.P., Mashud, N., Vu Thi My Lien, Kembu, A., Faure, M., Magdalita, P., Damasco, O., Novarianto, H. and Adkins, S.W. 2006c. Revealing the potential of elite coconut types. In: Coconut revival: new possibilities for the 'tree of life', Proceedings of the International Coconut Forum, Cairns, Australia, 22-24 November, (2005). Eds. S.W. Adkins, M. Foale and Y.M.S. Samosir, pp 43-48. ACIAR Proceedings Number 125. Publisher.

Samosir, Y.M.S. and Adkins, S.W. 2014. Improving acclimatization through the photoautotrophic culture of coconut (Cocos nucifera L.) seedlings: An in vitro system for the efficient exchange of germplasm. In Vitro. In Press.

Sisunandar, 2008. Cryopreservation for germplasm conservation of coconut (Cocos nucifera L). PhD Thesis. The University of Queensland.

Sisunandar, Sopade, P.A., Samosir Y.M.S., Rival, A. and Adkins, S.W. 2010a. Dehydration improves cryopreservation of coconut (Cocos nucifera L). Cryobiology 61(3): $289-296$.

Sisunandar, Rival, A., Turquay, P., Samosir, Y. and Adkins, S.W. 2010b. Cryopreservation of coconut (Cocos nucifera L.) zygotic embryos does not induce morphological, cytological or molecular changes in recovered seedlings. Planta 232(2): 435 447.

Sisunandar, Sopade, P.A., Samosir, Y.M., Rival A., Adkins, S.W. 2012. Conservation of coconut (Cocos nucifera L.) germplasm at 
sub-zero temperature. Cryo Letters 33(6): 465-75.

Sisunandar, Sopade, P.A., Samosir Y.M.S., Rival, A. and Adkins, S.W. 2013. Conservation of coconut (Cocos nucifera L.) germplasm at sub-zero temperature. Cryo Letters 33(6): 465-475.

Verdeil, J.L., Buffàrd-Morel, J., Rival, A., Grosdemange, R., Huet, C., and Pannetier, C. 1983. Coconut clones through somatic embryogenesis. In: Nair et al (Eds) Advances in Coconut Research and Development (pp 173-179). Kasaragod. Indian Society for Plantation Crops. 